\title{
Celebrating the feasts of the Old Testament in Christian contexts
}

\author{
Magdel le Roux \\ Department of Old Testament and Ancient Near Eastern Studies \\ University of South Africa
}

\begin{abstract}
Many early Christian churches incorporated a number of nonbiblical, even "pagan" symbols and rituals into their liturgy (e. g. the origin of Christmas). They were contextualized into the church by a brand new Christian content to them. From its first inception Christianity attempted to slander and suppress the pagan myths and rituals in the name of its own message. This, however, does not alter the fact that the church also sought some connections in the sphere of myth. Since the Reformation many Protestant churches have tended to "cleanse" the church from all forms of symbols and rituals that could be reminiscent of its earlier connection with the Roman Catholic Church. The article argues that this left an emptiness, a longing for symbols and rituals which usually form an essential part of a normal religious experience. The Old Testament has both a "deficit" and a "surplus" which might have an abiding significance for Christians. It has become clear from archaeological discoveries that Jewish societies formed an integral part of early Christian societies.
\end{abstract}

\section{INTRODUCTION}

The language of religion includes rituals and symbols, which are necessary in order to give expression to religious experiences. Symbols play a very important role in the encounter between God and human beings. The word of God is often expressed by means of language. In this respect the Hebrew people "are of special interest to the Christian reader because they laid the foundation of their distinctive religious language" (Fawcett 1970:204).

The ritual traditions of the Hebrews were gradually but radically transformed from a ritual life based upon and interpretative of the cycle of nature, to an understanding of their rites in terms of history. The nature-myth culture of the rituals was not abandoned, but a new dimension was added: the Hebrews turned the former into celebrations of those moments in their history 
when the hand of God had been manifested. Therefore, it is difficult to go back beyond the historical significance of a festival.

Furthermore the Hebrew people "gave birth to a sense of history which has been a decisive influence on the development of western thought" (Fawcett 1970:204). They seem to have been the first people to perceive their history in such a radical fashion that they transformed their whole manner of life in accordance with it. In this sense they became the people of a book which was a record of historical events, moments in which they had seen the hand of God (Fawcett 1970:204). It is characteristic of the Hebrew people that every event and especially every feast is used as a teaching opportunity ${ }^{1}$ (Poorthuis 1989:25). From history itself a lesson or two is to be learnt.

Many events were perceived as special to the Hebrews, but one experience stood out from the rest: the exodus from Egypt. Nothing was ever the same for them after that moment. It is extremely difficult to determine to what extent this consequence was understood at the time of the exodus, but it is clear that at some time subsequently it came to be seen as a moment of unclassifiable importance. The authors or compilers of the New Testament often refer to this memorable event in history and even furnish it with a new Christological interpretation.

Although the exodus tradition was dominant, other comparisons were also made. Jesus was, in particular, likened to Elijah who was to appear before the end, according to the prophecy contained in Malachi 4-5.

Jesus was not only born into the Jewish faith and genealogy (cf Mt 1:1), but according to the New Testament he obeyed God's commandments, celebrated each Jewish feast, and regarded all of the festivals as ordained by God to be remembered, observed and celebrated (cf. Wellhausen 1894 in Betz 1998:1-31). He said, "Don't misunderstand why I have come - it isn't to cancel the laws of Moses and the warnings of the prophets." "I am to fulfill them, and to make them all come true." "Those who teach God's laws and obey them shall be great in the Kingdom of Heaven" (Mt 5:17, 19). Jesus did not abolish the Torah, but he taught it in a way very different from other teachers (Betz 1998:2). In consequence, the symbolic language of Christianity at its birth was that of Judaism (Zimmerman 1981).

Wessels (1994:13) refers to the book of Miskotte, When the gods are silent: On the meaning of the Old Testament, which speaks of both a "deficit"

\footnotetext{
${ }^{1}$ On the doorposts of each house it is still customary for the Jewish people to nail a mezuza: the word, simply meaning "doorpost", came to be applied to a small box, made of wood or metal, in which a rectangular piece of parchment containing Deuteronomy 6:4-9 and 11:13-21 is set. The biblical basis for this practice is Deuteronomy 6:8: "You shall write [the divine words] on the doorposts of your houses and your gates." They [clarify: the Hebrews or the Jews, or both?] use every opportunity to teach the 'words of God' to their children.
} 
and a "surplus" in the Old Testament, by this meaning the abiding significance of the Old Testament for the Christians as well. Wessels (1994:13) suggests that we could ask whether we cannot also speak of a "surplus" in other religions, which continues despite, or perhaps precisely because of, their Christianisation. And is not this, as Eliade suggests, also the explanation of the success of the new, namely that to a certain degree it preserved elements of the old and thus consummated them? (Wessels 1994:13.)

Since the Reformation many Protestant churches have tended to "throw out the baby with the bath water" in the sense that the church was "cleansed" from all forms of symbols and rituals that could remind it of its earlier connection with the Roman Catholic Church. To my mind this left emptiness, a longing for symbols and rituals which usually form a crucial part of a normal religious experience. In many Reformed churches in Southern Africa today it seems to be the case that sensitivities to the implementation of rituals and symbols in the church as well as to the liturgical rhythm of the church year are developing more and more fully and frequently (Pieterse \& Muller 19[99] and cf Du Plooy et al 2000). For example, the mere presence of a cross or other symbols in various forms inside many Protestant and Evangelical churches, or the celebration of Passover, Palm Sunday and Advent by using decorations such as candles and other symbols, are quite new to most of the Protestant Churches in Southern Africa, but are very much welcomed by many of their members.

Much could be learnt from the Roman Catholic Church as far as rituals and symbols are concerned. To some extent much could also be learnt from the African Initiated Churches in South Africa as well as (Christian) Judaising groups in South Africa who have already succeeded in integrating some Old Testament rituals and symbols into their churches. But to my mind a more natural way for Protestants is to look in the direction of the Old Testament.

Poorthuis (1989:13) is convinced that a thorough knowledge of Jewish traditions could assist Christians to become better Christians. He takes the anti-Judaism warnings of the church fathers seriously, but is of the opinion that a better knowledge of Jewishness could make a more critical reading of the church fathers possible. The enormous quantity of rabbinic and patristic literature and archaeological evidence could still contribute to the better understanding of certain biblical passages.

In my opinion it could be a worthwhile endeavour to consider possible Old Testament symbols and rituals as they were used and celebrated by the Early Christians. What could possibly be learnt from the teaching of the church fathers? And can any signs of Jewish-Christian ties be found in archaeological remains from that period? I do not pretend to have carried out 
a thorough investigation into the early church or the patristic one, but my main focus lies on the "surplus" that the Old Testament might offer for Christianity today. I am investigating the possibility of applying some of those rituals and symbols in Christian homes and churches, instead of using the "surplus" from other religions or other "late comers" on the religious scene. In this regard I rely heavily on the work done by Zimmerman (1981).

\section{OLD TESTAMENT SYMBOLS AND RITUALS IN THE EARLY CHRISTIAN CHURCH, AS REFLECTED IN ARCHAEOLOGY AND PATRISTIC LITERATURE}

\subsection{Patristic literature}

When the reorganization of Judaism took place at Jamnia (after $70 \mathrm{CE}$ ), it became the considered conclusion that prayer in the synagogue was a viable and acceptable substitute for the sacrificial system in the Temple. The daily sacrifices in the morning, afternoon and evening were replaced by a daily synagogue worship at the same three times of day. On the Sabbath morning the daily sacrifice was supplemented by an additional offering; the Sabbath morning-prayer period was supplemented by an additional sequence of prayers (Sandmel 1978:150, 151).

According to the "Legends of Simon Cephas', in Rome, Peter played a distinctive role in the separation of Judaism and Christianity (Van Bekkum 2004:296-306). The words and acts of Simon Cephas in this text constitute a request for the Christians to leave Judaism to the Jews and to follow new guidelines concerning the Jewish festivals. He commands the Christians not to celebrate the Feast of the Unleavened Bread but instead to celebrate the day of Jesus' death. Shavuot is equated with Ascension Day (not with Pentecost), while the eight days of Sukkoth (the Feast of Booths?) are transposed to Christmas and the New Year, the festivals of Jesus' birth and circumcision. Instead of the Feast of Weeks, Christians will celebrate the forty days from the moment he was stoned until his ascension to heaven. However, Simon Cephas's determination to remain loyal to Judaism is expressed in his faith in the God of the Patriarchs and the composition of liturgical hymns or piyyutim (Van Bekkum 2004:296-306).

During the reign of Trajan (98-117CE), Ignatius, the bishop of Antioch, in Syria, was arrested and transported to Rome to be executed in the Colosseum. In his letters to the Roman Christians, he is concerned with divergent Christianity, by which he must mean a form of Jewish Christianity which emphasized observance of the Sabbath and dependence mainly on the 
Old Testament (Tyson 1973:156). The Epistle of Barnabas similarly condemns the Jewish sacrifices, as well as the observance of the circumcision, Sabbath and food laws, but the writer holds to the authority of the Old Testament (Tyson 1973:160).

Near the end of the reign of Marcus Aurelius (161-180 CE), ca 178, the well-read provincial, Celsus, perhaps a Syrian, set out to analyze the new Christian religion and to warn his fellow provincials of the danger of its spread (Frend 1988:54). He concludes that the Christians were simply "apostate Jews", whose attitude towards the gods and their fellow men differed hardly one whit from that of their Jewish forebears. About 170, Heracleon, Celsus' contemporary, makes much the same point, accusing the ordinary (i.e. orthodox) Christians of "worshipping as Jews" and of celebrating the Jewish Passover in the Eucharist (Frend 1988:55).

According to Eusebius, Melito, bishop of Sardis, was one of the most prolific writers of the ancient church. One of his sermons, dated in 167-168AD, focused particularly on the Passover. This ritual holds a dual significance for him: it is both a Jewish institution commemorating a historical event and a "type" of the sacrifice of Jesus (Tyson 1973:249). Melito's typological interpretation became an exceedingly useful tool for proto-catholic and later Christianity (cf Chupungco 1992:1).

The accepted teaching is that Easter as concept and as celebration embraces both the death and glorification of Christ. The Easter triduum, which may be regarded as one prolonged liturgical day, is a fitting embodiment of this theology. St Ambrose of Milan (Ambrose of Milan, Letter 23, 12-13 [PL 16:1030]) spoke of the "sacred triduum" or the three days when Christ "suffered, was laid in the tomb, and rose again". St Augustine (Augustine of Hippo, Letter 55, 24 [PL33:215]) understood the triduum as encompassing the three days in solemn remembrance of "Christ crucified, buried, and risen."

The New Testament offers no explicit information as to whether the apostles annually celebrated the Christian feast of Easter. Chupungco (1992:9) argues that from the solemn declaration of 1 Corinthians 5:7b-8, "Christ our Passover has been sacrificed; let us celebrate the feast", we can at least conclude that the apostolic church attributed to the Jewish feast of the Passover a Christian meaning. However, ample evidence exists that the first disciples of Jesus observed the feasts of Passover, Unleavened Bread, and Pentecost (cf 1 Cor 5:7b-8; Ac 20:16; Ac 20:6). Chupungco (1992:10) remarks, "the dynamic of inculturation at this early part of liturgical history would not have required anything more than a reinterpretation of these feasts in the light of the saving work of Christ. Inculturation does not necessarily involve a change in existing ritual patterns and elements of the feast. What it 
requires is a change of perspective, a new manner of understanding the meaning of the feast."

An outline of the liturgy for the second Christian century is given in the Apostolic Tradition of Hippolytus, the first "Service Book" of the church (Carrington 1957:336-350; Houtepen 2004:438; cf Geerlings 1991:211). The text of the bishop's Eucharistic Prayer in Hippolytus is free from the old Jewish associations with the fruits of the earth, which are strongly represented in the Didache and Justin and Irenaeus; but the ordination and baptismal Eucharists both retain traces of them in the offerings of oil, cheese, olives, milk, and honey; and the offering of the fruits of the earth continued in the Roman rite for a long time and has never become quite extinct. Hippolytus preserves some of these old Jewish rites as separate features, the offering of first-fruits for instance, and the benedictions over various gifts of nature. We also find the "agape" or love-feast, in which some rich person provides a supper in the evening for less privileged brothers and sisters. There were prayer and the reading of scriptures; the bread was broken and blessed by the bishop, who was to be present if possible; otherwise by a presbyter or deacon. Each guest said the "Eucharist" or thanksgiving for him/herself over his/her own cup.

The bishop was also the normal officiant at the offering of the firstfruits, at which he uttered a benediction into which he inserted the name of the giver. The blessing of the first-fruits is also called a eucharistia (the bread of the sacrament). The first-fruits were doubtless offerings made according to Jewish precedent and devoted to the maintenance of the church and clergy, as in the Didache ${ }^{2}$ (Carrington 1957:341).

We not only find the inculturation or Christianisation of Old Testament rituals and practices in the early Christian church, but also the Christianisation of pagan festivals - to mention only two examples, the celebration of Christmas and Easter in the early church. ${ }^{3}$ According to Sandmel (1978:419) many of the Jewish sacred days, and the vast array of all Pentateuchal laws, are not preserved in Christianity. The New Year and the Day of Atonement are not carried over, for Christianity innovated its own atonement system.

\footnotetext{
${ }^{2}$ The day (lag be-omer) became in medieval times a festive day, especially in Rabbinic academies; the "scholars" festival' became an occasion of great merrymaking (Sandmel 1978:456).

${ }^{3}$ Wessels (1994:41) illustrates, from Christmas, how in the Graeco-Roman context this festival of the birth of Jesus came to be combined in a specific way with the feast of Mithras. The latter was an Indo-Iranian god who is already mentioned in the fourteenth century BC. He was the "light bearer" sent to earth to bring fertility. Like Christmas, the Christian Easter took up a pre-Christian festival in Europe. The English and German name Easter/Ostern has no connection with the Greek pascha, which provides the name in French and Dutch (Wessels 1994:154ff). It is very probably taken from the name of the Saxon goddess Eastre or Ostara, the goddess of eggs and of the spring. Oestrus (from the Latin) has to do with fertility.
} 
Passover is preserved, altered into Easter, and Pentecost, Shavuot, is given a new interpretation, as part of historic Christian experience, in Acts 2. Sukkoth was not carried over and the Sabbath remained, but was shifted to Sunday; the essentials of the Sabbath mitzvoth and halachot were abandoned. Retained in the alteration was the emphasis on the Sabbath as the preeminent weekly day of prayer, along with the reading of Scripture.

To what extent the Jewish and pagan communities were integrated with Christian ones is not clear. Both heathen and Christian writers dating from the early Christian period (the 4 th to the $6^{\text {th }}$ century $A D$ ), complain constantly about the fact that the ancient society (of Rome) was subjected to the process of transformation and disintegration (Hieronymus, Ep 128.5; Claudianus, De bello Gild 1.21-25; Namatianus, De red suo 1.47 en passim; Hydatius, Chron 1-6). According to those authors the disintegration is embodied mainly in the invasion of Rome in 410 CE by the (Visigothic) armies of Alaric. Rutgers (2004:6), a historian of religion and archaeologist, is convinced that the study of this period (late $3^{\text {rd }}$ century to the late $6^{\text {th }}$ century) is without doubt one of the most promising areas of investigation at present. Peter Brown (2003:1) describes this research area as being subjected to a real "breach in a dike" of new and renewing research. It seems that the Roman style of living simply continued after the fall of the Roman political structure. It might also have continued as a result of the old economic structures that were still in place. Recent archaeological research has showed that along with the fact that early Christianity was characterized by internal discord, all kinds of pagan, that is polytheistic, groups did not just disappear all of a sudden (Rutgers 2004:8). This period is characterised in particular by the continued process of interaction between groups of divergent political, social and religious signatures. Rutgers (2004:8) especially emphasizes the importance of the interaction between Judaism, Christianity and paganism.

\subsection{Archaeology}

- In the light of archaeological discoveries during the previous fifty years it has become clear that Jewish societies formed an integral part of those early societies (until the $6^{\text {th }}$ century). To what degree those Jewish communities were integrated with Christian communities is not yet certain, but the implications of the discovery of a complex of Jewish catacombs underneath Villa Torlonia (at the Via Nomentana), in Rome, dating from this specific period in time, are enormous (Rutgers $2004: 13,14)$. The location, as well as the dating, of those Jewish catacombs (in "traditional" Christian burial places), elicit a number of questions as far as the influence of the Jewish people on early Christianity is concerned. 
Dutch-based researchers report that this complex of Jewish catacombs (Villa Torlonia) predates its Christian counterparts. Using radiocarbon dating techniques, the team found that charcoal fragments embedded in lime powder used in the construction of Villa Torlonia dated from $50 \mathrm{BC}$ to $\mathrm{AD} 400$. The discovery suggests that the Jewish catacomb came into use a century before the earliest Christian sites (Owen 2005). It also suggests that the Jewish roots of early Christianity run far deeper than previously thought. The period of separation between Christianity and the Jewish influence took much longer and was much more gradual than was thought. Rutgers (in Owen 2005) argues: "These catacombs are the earliest archaeological evidence we have for Christianity. As such, they remain potent Christian symbols."

The archaeological discovery could also shed new light on the JewishChristian relationships in the "eternal city" and on the anti-Judaism writings of the church fathers. For many pilgrims and tourists, the ancient catacombs of Rome represent the rise of Christianity, yet this new research suggests that these vast underground burial complexes may owe their origins to Jews.

- Books on ancient architecture often emphasize that, in antiquity, the use of mosaics involved a much cheaper technique for paving floors than the use of marble and multicolored tiles. For the archaeologist and the public the less expensive method is more interesting, owing to the fact that the use of mosaics enables one to produce artistic designs. Even more important is that inscriptions may be inserted into mosaic pavements (Vriezen 1998:247-261).

Inscriptions found in the Palestine/Arabia area, in the $5^{\text {th }}-8^{\text {th }}$ centuries, representing texts from the Old Testament, are of special interest here. Many of these inscriptions were generally placed near the entrance of ancient churches and synagogues or at the altar. The quotations originated mainly from the Psalms but also came from 1 Kings (2:13); 2 Kings (2:21b); Deuteronomy (7:12b-13; 28:6); Proverbs (13:9); Isaiah (65:25; 11:6-8); Daniel (6) and Genesis (6-9). In a number of cases there existed a relation between the content of the texts and the location of the inscription and in other cases the inscriptions quoting the Old Testament texts are accompanied by a figurative depiction of the text. It seems that the use of some of these texts was inspired by the fact that, occasionally, they were recited in both Jewish and Christian 
liturgy. Other inscriptions quote texts that were recited in early Christian liturgy as well as in Jewish prayers, or which represent prayers and invocations, either anonymous or for the wellbeing of named individuals or the groups commemorated (Vriezen 1998:247-261).

- Mushrooms and snails comprise two rare elements of early Christian iconography and hint at ritual meals and agape feasts enjoyed by early Christians. The mosaic floor of the northern hall in the ancient Christian basilica at Aquilleia, dating back to a period set before 330AD, reproduces several symbolic objects and pictorial scenes. Among these a basket with mushrooms and another with snails deserve special attention. The snails have been identified as Helix cincta but the identity of the mushrooms is more difficult to determine. Several hypotheses regarding the presence of the mushrooms and the snails in the basilica have been proposed: i) both merely represent simple decorative motives, ii) they symbolize typical nourishment served during holy banquets or iii) they were ingested by the (initiated) audience of liturgical celebrations in order to attain ecstasy (Fabbro 1999).

Religious customs in early Christianity exhibited so many features in common with early Judaism, and in particular with apocalypticism, that it is most likely that a transmission occurred from early Judaism to early Christianity of the techniques for reaching ecstasy and perceiving visions. Philological studies in the past suggested that some early Christian groups also made use of Amarita muscaria as a hallucinogenic substance during specific religious rites. This hypothesis has been vigorously contested, in particular because no historical data were said to be available in order to support this claim (Fabbro 1999).

\section{CELEBRATING OLD TESTAMENT RITUALS AND SYMBOLS IN THE CHRISTIAN CHURCH OR HOME}

The Old Testament is a great and inexhaustible resource for $20^{\text {th }}$ century Christians. One of the most overlooked areas involves various feasts, celebrations and other family events outlined by God for Israel to take part in. These were intended to help Jewish parents to teach their children, in a clear and dramatic style, about God's love, care, and will for Israel. Some of those Old Testament experiences can be made relevant in Christian contexts today. I would not advocate that these activities be normative and obligatory for Christians today, but they could add value, meaning and knowledge to the 
understanding of biblical events and enrich the understanding of who God is and what He can do in people's lives.

I will now discuss some of the Old Testament feasts which Zimmerman (1981) finds suitable for celebrating in Christian contexts - Sabbath, Passover, Omer, Shavuot, Rosh Hashanah and Yom Kippur. Some of those celebrations are not found as such in the Old Testament, but have been influenced by modern Judaism.

\subsection{Sabbath}

The word Sabbath comes from the Hebrew word Shabbat, meaning "rest". Following the text of Leviticus 23, God's first appointment with his people is for the Sabbath (cf Le Roux 2005 on the interpretation of the Sabbath). According to the Bible, God said to Moses: "Speak to the sons of Israel, and say to them, 'The Lord's appointed times ... are these.'” The Sabbath seems to occupy the primary place on this list of holy days, both in its position and frequency. Genesis 2:1-3 indicates that the Sabbath was instituted as a memorial of God's creation. It was so important that it was included in the Ten Commandments, "Remember the Sabbath day, to keep it holy" (Ex 20:8-11), and in Deuteronomy 5:12, "Observe the Sabbath day to keep it holy ...." (Zimmerman 1981:23)

Zimmerman (1981:23) holds that the two words, "remember" and "observe" tell the reader something of how to approach and live out this day. "Remember" includes inward thoughts of love and devotion and "observe" combines love and devotion. Hebrew tradition tells us that as God presented the commandments, He spoke to Moses and said, "I have a precious gift stored away in my treasures and its name is Sabbath. I desire to give this gift to Israel. Go and inform them of it." Zimmerman (1981:23) emphasizes that people often miss what God intends for their good and that before long this day, that God had planned for his people's good, instead became filled with "thou shalt nots", almost to the exclusion of recreation. In the New Testament Jesus reminds Israel to observe the Sabbath as a delight, not a burden: "The Sabbath was made for man and not man for the Sabbath" (Mk 2:27); "I desire compassion, and not a sacrifice ... " (Mt 12:7); "It is right to do well on the Sabbath" (Mt 12:12). Jesus' teaching and actions were misunderstood on various occasions, but it seems that He loved and observed the Sabbath, He even declared himself to be the "Lord of the Sabbath."

The Pharisees took the commandment "to rest" and carried it to ridiculous extremes which distorted the original purpose and in our day some people still overreact against Sabbath and Sunday restrictions and forget the importance of the day. In a world where people are so busy and life has 
become hectic and exhausting, the Sabbath is "a gift of time". It is a day supposed to be filled with special joy, as the family gives the gift of time to each other (Zimmerman 1981:24). Zimmerman is convinced that it could still serve a purpose for Christians.

\subsubsection{Sabbath Friday}

Zimmerman (1981:24-48) describes in detail for a modern reader the preparations for Sabbath Friday (cf Lk 23:54; Dt 14:26b): what you will need and how to celebrate it. All the preparations, taken with care and forethought, are part of the celebration and the "getting ready to" part of the festival. The house should be cleaned, special foods are prepared, the table is set with your best, and candlesticks are polished and put in place (cf Zimmerman 1981:47, checklist for the weekend events). The family is being honored by this attention, not "special" guests. The purpose is for the family to be together; therefore everybody helps in the preparations. She discusses in detail how the meaning behind the different Sabbath symbols should be explained to the family, first within the Old Testament context and then also from a Christian perspective. ${ }^{4}$

\footnotetext{
${ }^{4}$ Sabbath Friday:

Candles: In ancient Israel, a blast from the shofar, the ram's horn, signaled that the people of Israel should stop working and begin to observe the Sabbath. Just before the sun set, lamps were lit in homes to shine through the dusk and dark hours. The tradition of lighting candles has continued. The mother lights the Sabbath candles because it was Eve, the first mother, who extinguished the light of eternal light by disobeying God's command not to eat from the tree of knowledge of good and evil (Gn 2:17). Two candles are lit: the one represents "creation" and the other one 'redemption' or they may also be symbolic of "remember" and "observe". In some Jewish homes a candle is lit for each member of the family; others say they glow for the harmony of the home and still others believe they encourage Sabbath joy (Zimmerman 1981:26-27). When the mother lights the candles Zimmerman (1981:28) contextualizes this ritual by reminding Christians that God chose another woman, Mary, to bring forth "The light of the world" (Jn 8:12). Each week this picture can be seen on the table: The two candles, symbolic of creation, which Sabbath celebrates, and of redemption, Christ, the Light of the World.
}

Wine: Zimmerman (1981:28) writes that "a goblet of wine is placed next to the candlesticks on the table. A sanctification prayer called the Kiddush is recited by the father over this symbolic cup". The Sabbath meal begins with a kiddush (sanctification), a ritual in which wine was drunk, and bread, broken and dipped in salt, was eaten (Sandmel 1978:212). The wine symbolizes life, joy and fullness. The cup is held at the base by the fingers, causing them to point upward, reaching up and longing for God. It is passed to each member of the family. The wine also symbolizes Christ's shed blood (Zimmerman 1981:28).

Washing: The blessing which is recited before the hands are being washed is intended to show gratitude to God for the sanctification of his people. The prayer is a 'dedication' of the hands, of the people themselves, to God. The washing of the hands and the raising of the hands to God signify that the real needs of people are on a higher level. A bowl of water and a towel are placed on the table and passed on to each member of the family (Zimmerman 1981:29). 
The essentials of the Sabbath mitzvoth and halachot were abandoned by early Christianity, but the emphasis on the Sabbath as the pre-eminent weekly day of prayer (now on a Sunday) along with the reading of Scripture was retained in the alteration (Sandmel 1978:419).

\subsubsection{Sabbath Saturday}

"Waking up on the Saturday morning one should remember that you are in the very presence of God", says Zimmerman (1981:31): "Be glad in the Lord and rejoice ... shout for joy" (Ps 32:11). Whatever you do on this day, you should do it "all to the glory of God" (1 Cor 10:31). In Hebrew tradition the Word of God is central to this day. It should be read and studied, as meditation on the teachings of the Lord. In contrast to the busyness of the Friday with all the preparations to be made then, the Saturday should be free from work.

When the sun starts to set, the family again gathers around the table to enjoy a very simple meal, with very light refreshments. "The ceremony of Havdalah, which means separation, concludes the Sabbath and introduces the new week. The candles are twisted together for the service, linking symbolically the two candles of the Friday night's Sabbath table, which presented "Creation" and "Redemption" (Zimmerman 1981:32). Usually the children in the house will light and hold the candles as well as a little spice box (filled with cloves). Zimmerman (1981:32) suggests that the family then reads passages from the Bible (e g Jn 1:1-17; Lk 23:54-56; Lk 24:1-8). The wine glass is filled and overflows as a sign of fullness and the completion of the week. The father leads the family in prayer: a benediction with thanksgivings to God. The twisted candle is extinguished by dipping the flames into the

Bread: Sabbath bread is called challah, a term used for new dough, which was the requirement for it to be presented as a 'gift to the Lord' (Nm 15:17-21). Leviticus 24:5-9 prescribes that loaves of bread be placed on the altar before the Lord. This was to be done on the Sabbath as a sign of the everlasting covenant between God and his people Israel. 'Two loaves appear on the Sabbath table, symbolic of the double portion of manna which God provided on Friday for the children of Israel during the years they wandered in the wilderness.

Fulfilling His requirements for rest, no manna fell on the Sabbath (Ex 16; Zimmerman 1981:30). The bread is covered with a special cloth, symbolizing the dew that surrounded the camp when the Israelites woke up in the desert and were reminded that God does provide. Before breaking and eating the bread, the challah is blessed. At this stage all the knives on the table should be covered, symbolic of Isaiah 2:4 (cf Ex 20:25). Instruments of war are to be put aside since the Jews deplore violence and long for peace. The bread should be 'broken', according to Zimmerman, symbolizing Christ's broken body. After the blessing, salt is sprinkled on the bread, recalling Genesis 3:19. Because it is not from man that we receive our bread, it is customary for each person to break off his/her own piece, remembering that God gives us our daily bread (cf Mt 6:11) and each person expresses his/her own 'thank you' to God as he/she receives this gift (cf. Ecc 9:7; Zimmerman 1981:30,31).

Grace: Deuteronomy 8:10 expresses this as follows: 'When you have eaten and are satisfied, you shall bless the Lord your God for the good land which He has given you.' The chapter reminds one that when everything is going well people tend to become proud and forget the Lord. Verse 18 - "But you shall remember the Lord your God" (Zimmerman 1981:31). 
spilled wine. Then the family passes the box of spice from person to person. The fragrance signifies the life which has just been experienced in the Sabbath. The fragrance will carry you through the pressures of the week until the next Sabbath (cf Sandmel 1978:212).

Zimmerman (1981:33) notices a striking symbolism here. Referring to texts such as John 19:30, Luke 22:19-20, Luke 22:42 and Luke 23:56 she stresses that the light of the world was extinguished for three days, as Jesus" blood had been spilled. Then the women prepared spices to anoint his body, which could signify the fragrance of the life experienced in Jesus (Jn 10:10). After reading those passages together, Christians could collectively repeat the twenty-third Psalm: "Thou preparest a table before me in the presence of my enemies: thou anointest my head with oil; my cup runneth over" (Ps 23:5). Zimmerman (1981:33) observes many elements in the Sabbath celebration which could be taught and which remind her about God but which could obviously not be discussed here in detail. She concludes (1981:34) her discussion by saying that "[t]he Sabbath is symbolic of Christ. The Old Testament teaches 'get ready to observe'. Jesus, our Sabbath, enters .... The New Testament teaches "remember Me" with joy!'

\subsubsection{The first day of the week, Sunday}

It is the custom of the Christian world to celebrate Sunday, the first day of the week, Christ's resurrection (cf Lk 24:1-8), by going to church to worship him and to fellowship with his people (cf Lk 4:16). Zimmerman (1981:35) suggests that the celebration of this special day could be enhanced by lighting a big, bright candle and a card containing some special verses from the Bible for the day and placing it on the breakfast table early in the morning. She also recommends an "Emmaus walk" for the family on Sunday afternoon and encourages them to converse and discuss with each other about "all the things which had taken place" (cf Lk 24:30-50). Zimmerman's family sometimes gathers around the table for a havdalah service on Sunday night instead of Saturday night and lights the candle for the breakfast table on Monday. They also remind each other that Jesus has risen, that He is going with them through the week, and that even as the Father sent him into the world as a witness, He has sent them to be his witnesses (cf Zimmerman 1981:36-50 for special recipes and prayers).

\subsection{Passover/Pesah/Seder}

The essence of the Passover can be found in Exodus 12:1-14 when God ordered Moses in the land of Egypt to speak to all the congregation of Israel, instructing them to take a lamb, an unblemished male a year old, and to kill it in the twilight on a specific day: 
$[T]$ hey shall take some of the blood and put it on the two doorposts and on the lintel of the houses in which they eat it .... And the blood shall be a sign for you on the houses where you live; and when I see the blood I will pass over you. For I will go through the land of Egypt on that night, and will strike down all the first-born in the land of Egypt, both man and beast; and against all the gods of Egypt I will execute judgments - I am the Lord. Now this day is a memorial to you, and you shall celebrate it as a feast to the Lord; throughout your generations you are to celebrate it as a permanent ordinance. ${ }^{5}$

In time Moses (according to the Old Testament) appointed men, priests, whose main task it was to see that the people never forgot what happened that night they ate the Paschal lamb. The lamb kept alive Israel's faith in God. And the Lord told them that the first-born of their sons should be given to him and that they should do the same with their sheep. The first-born of the beasts were to be sacrificed and the first-born sons were to be redeemed with a lamb (Ex 22:29, 30; 13:11-15; 34:19-20; Dt 16:1-8).

It is unnecessary to speak of the deep symbolic significance that Christians find right through the Bible in this regard, and just a few examples will suffice: Zimmerman (1981:52-55) shows how Jesus' earthly ministry was introduced with a quotation from the prophets, "Behold, the Lamb of God who takes away the sin of the world" (Jn 1:29). Utterly defenseless, like a lamb led to the slaughter, He offered himself, his body and soul, as a ransom, an offering, a sacrifice for sin and sinners. The Paschal Victim became the sacrifice of the New Covenant which was offered for all people (Lk 22:20). There were many types of sacrifices in the Old Testament - most were due to God and belonged to him. Zimmerman (1981:56) concludes that God sacrificed the Lamb on the altar of the cross and that God promises to pass over his judgment of death for those who are willing to stand under its protection. This is what Christians remember and celebrate at Passover (Ex 12:13).

\subsubsection{Palm Sunday}

The Passover celebration starts with Palm Sunday. Many Christian congregations today celebrate this Sunday in their churches. Usually children will enter the church holding palm branches, singing a song referring to Jesus who entered Jerusalem on a donkey and to the crowds who welcomed him

\footnotetext{
${ }^{5}$ Owing to the limitations of space and to the boundaries of the present research I will not consider the theory that Passover was originally a pastoral rite held by nomads once a year in spring, while the feast of Unleavened Bread was an agricultural rite performed, also in spring, by Canaanite farmers.
} 
with branches and clothes thrown onto the street. The latter wanted to crown him as king, but he refused this honor.

\subsubsection{The night before Passover}

On the Thursday night before Passover, Christian families could gather together and read Exodus 12:15, 19, 42. In the Old and New Testaments leaven or fermented items often symbolize sin. Jesus warned against the "leaven of the Pharisees and Sadducees" (Mt 16:6) and Paul wrote of "the leaven of malice and wickedness" and the "unleavened bread of sincerity and truth" (1 Cor 5:8). For Christians the Passover bread described in Exodus was to become a symbol of the sinless Christ. The instructions are clear unleavened bread is to be used exclusively for seven days. The Hebrews clean, scour, and scrub anything that might have had "contact" with leaven during the year. In Hebrew tradition the ceremony associated with cleaning out the leaven is called bedikat chametz, the search for the leaven. After dark the father of the family leads a search with a candle's light through all the corners of the house. If the mother, or whoever cleans, did a good job, no leaven would be found (Zimmerman 1981:58-59).

In some Christian families, says Zimmerman, 12 pieces of white bread would be hidden in the living-room area (Zimmerman 1981:59). They could turn off the lights and light a candle to search in the darkness for the "leaven", thus remembering Christ, the light of the world, who sees sin in our lives, offers to remove it and shows that some pieces (sin) are well hidden, until Christ's light shines on them (Zimmerman 1981:59). They could then pray in response to this experience, turn on the lights and read Psalm 103:12. They store the pieces of bread in a small bag and use them in the morning.

\subsubsection{The morning of Passover}

Zimmerman (1981:60) explains how some Christian families would light a small fire (in a safe place) and after reading 1 Corinthians 5:6-8, they would burn the bread, bag and all. They say together: "Christ our Passover has made us unleavened. Thank you Jesus."

Passover is intended mainly for the children (Ex 12:14) and it is for the home. The instructions say: It is to be eaten in a single house (Ex 12:46). At least four times it is repeated that God commanded Moses to instruct a father to tell the story of the Exodus to his children (Ex 12:26-27; 13:8, 14; Dt 6:2021).

The Passover celebration is called "The Seder", which means "order". The intent of the ceremony is to ".... tell thy son and daughter." Zimmerman (1981:61) finds it a very impressive way to teach children, and is convinced 
that it is entirely a "home" ritual. Central to the celebration is the symbolic meal to which the entire extended family is invited. Each person should bring a jacket or sweater to his/her place at the table in keeping with Exodus 12:11: "Your sandals on your feet, and your staff in your hand." Zimmerman suggests that in Christian homes one could read Luke 12:35: "Be dressed in readiness, and keep your lamps alight." The table is covered with a white cloth, using the best they have. An extra setting and chair is reserved for the prophet Elijah, who, according to Zimmerman (1981:62), came as John the Baptist (Mt 11:14; Lk 1:17). It is the mother who lights the candles at all festival celebrations (see 3.1.1).

\subsubsection{Passover/Seder evening}

When the first stars become visible the Seder evening begins. During the feast of the Exodus, the Hebrew people celebrate the nobility of all free people. Every free person is a member of the nobility; every Jew is on Seder evening a king. Therefore, on this evening, they will allow others to serve them and many people will have an armchair or pillow to lie at the table while eating (Poorthuis 1989:27; cf Rabbi David 2005 at Taize). That is, to eat as a free, wealthy person - who can eat slowly, while talking about the departure from Egypt. After the Talmudic period the Jewish people noticed how the Romans ate and decided that they would eat the Seder like wealthy, free people, not like slaves: almost the opposite of what we read in Exodus - to eat quickly. This is perhaps how Judaism has survived - making it relevant for each period (Rabbi David 2005). The eating of the Seder has been transformed to be quite different today - combining the customs of wealthy people to tell the story of what was. It is told in such a way that each Jew feels that they are departing from Egypt that same night - with abundant joy, singing their most popular song - "We were slaves, now we are free people!" (Rabbi David 2005).

See, think, eat, internalise all symbols. To the children tell the story of what happened. After four glasses of wine (each for a specific purpose) you tell the story even better, says the Rabbi. To eat and to drink joyfully is all about being a free person.

\subsubsection{Passover symbols and their meaning}

Haggadah signifies "narration" or "recital". It is the name given to the text used for narrating the story of the Exodus, which is the central activity of Passover. The questions usually asked could be: What do you remember about leaving Egypt? Or, why do we celebrate Passover, Father? The story is then retold in their own words. 
Kiddush denotes "consecration" or "sanctification". Holding the first cup of wine or juice in his right hand, the leader begins the Seder by reciting the Kiddush. ${ }^{6}$ Wine is the symbol of joy (Ps 104:15) and therefore reminds the participants of the joy which is theirs as a result of their salvation (Zimmerman 1981:63). The Haggadah brings hope and promise; it emphasizes that redemption is available to all.

A special invitation is directed to the participants: "Let all who are poor come and eat, let all who are in need come and make the Passover." Zimmerman (1981:63) adds a Christian meaning to this invitation: Jesus says, "Come to me, all who are weary and heavy-laden, and I will give you rest" (Mt 11:28). A pitcher of water, a basin and a towel are brought to the table and the head of the house washes and dries his hands. This imitates the actions of the priest who washed before entering into the Holy of Holies. Zimmerman (1981:63) reminds one how Jesus once taught his disciples a lesson in humility by washing their feet.

Karpas: Taking a piece of parsley, the leader dips it in salt water and gives it to each member of the family and himself as a symbol of how God brought them safely across the Red Sea (salt water) and made them a new nation (green vegetables). Rabbis usually give three names to the three loaves of unleavened bread (Matzoh): Kohanites, Levites and Israelites. Unleavened bread is made of pure flour and water, without yeast to ferment and sour it. Yeast vividly pictures what sin does to a life. The blood of the innocent Passover Lamb became the symbol of an innocent life covering a guilty life from the eyes of a holy and just God (Ex 12:13). "When I see the blood I will pass over you ...." (cf 1 Cor 5:7; Zimmerman 1981:65). Hebrew people, since the destruction of the Temple, have been unable to observe the Passover according to the Law of Moses. The law laid down that the Passover Lamb was to be offered only in the tabernacle where God had placed his name (Dt 16:5,6; $1 \mathrm{Ki} \mathrm{9:3).} \mathrm{In} \mathrm{the} \mathrm{years} \mathrm{that} \mathrm{followed,} \mathrm{the} \mathrm{Jews} \mathrm{have} \mathrm{provided}$ a symbol for the Passover lamb by placing a roast lamb shank on a plate. The rabbis added an egg as a reminder of the Hagigah, the "voluntary peace offering" on the second day of Passover (Zimmerman 1981:65). All these actions direct Christians to Christ (cf 2 Cor 5:19), argues Zimmerman (1981:65).

The charoseth is a mixture of coarsely chopped fruit and spices which resembles, in color, the clay or mortar that the Israelites made in Egypt. The maror or bitter herbs are symbolic of slavery and misery (Ex 1:14; cf Sandmel

\footnotetext{
${ }^{6}$ Much of traditional Judaism as practiced by observant Jews today was fully shaped in the ancient Rabbinic era. However, the prayer known as the Kiddush arose only in medieval times (Sandmel 1978:199).
} 
1978:213). The meal begins with a hard-boiled egg in salt water. The egg represents the hardness of Pharaoh's heart and the salt water, the tears of the Hebrew slaves under Egypt's bondage.

The afikoman is a broken piece of matzoh that was hidden away early in the service. Meaning "dessert", it is to be eaten at the end of the meal. Sandmel (1978:214) points out that the danger could exist that an excess of wine might cause the religious recitation to become distorted into drunkenness by the close of the meal. Therefore, a piece of matzoh is eaten to signify that the eating and drinking are ended. After the meal, grace is said to bless the Lord God for all that He has given his people (Dt 8:10). The cup of wine is poured for Elijah and the Jewish children will open the door to allow him to enter and to remind them that the Messiah will come. In Christian tradition this represents the belief that John the Baptist will enter and announce that the Messiah has come (cf Poorthuis \& Schwartz 2004:351).

Poorthuis (1989:28) considers that the meal is pre-eminently the place for the experience of the religious dimension of life and for the transmission of faith. Jewry and Christianity share this fundamental principle in common. The meal brings about a special bonding between friends and family and a feeling of care and community. The purpose of the Jewish blessing over the bread and wine is to elicit a feeling of awe: "Wie eet zonder een zegen uit te spreken is een dief van de Allerhoogste" (He who eats without saying grace thieves from the Almighty), say the Rabbis. The Jewish people keep their religious wonder alive through offering prayer and benedictions in many different situations.

For the children there is much to see and they will immediately notice the difference from other evening meals. As already mentioned, one of the well-known questions posed by the youngest child is usually (Poorthuis 1989:28): "Why is this evening different from all the others?" This question is crucial for the smooth celebration of the Seder. Only in hearing the voice of the youngest child (asking this question) can the feast of liberation be declared a success.

Many ecumenical or "Zamen op weg" churches in The Netherlands include this crucial question (and other elements) in their special celebration on the Saturday night after Passover: the so-called evening of the "Paaswake". First some Scripture reading, teaching, singing and prayers take place, together with all present. Then at a certain point all lights will be extinguished. Subsequently, when some of the clergy, accompanied by children, enter the dark church with the "Paaskaars" or Easter Candle (symbolically bringing the light into the darkness) the youngest child will ask this question out loud to the preacher. He/she then answers the child's 
question, telling the story of the redemption from Egypt to all present. They place the new "Paaskaars" in front of the church and then the celebration begins. This usually happens around midnight. Those who want to, now walk to the front of the church to commemorate their own baptism by taking water from the baptismal font and drawing a cross on their foreheads with the water. The celebration usually ends by everybody drinking a glass of sweet wine with the rest of the congregation. Each person receives a small candle when leaving the church. Everybody leaves the church with his/her candle lit from the Easter Candle, symbolically taking the light into the darkness (Van der Beld 2000a, 2000b).

It is almost possible to interpret the Jewish way of teaching by means of this one question concerning the meaning of the evening. To mention just a few things: The child does not ask intellectual concepts or abstract religious themes, but enquires about what he or she sees, tries out and does himself. Verbal teaching is very important in Jewry, but religion as an attitude of life can only be practiced by acts, deeds and rituals, day by day. Poorthuis (1989:29) is convinced that people are not formed by concepts, but by their deeds. This ceremony pivots on the question asked by the youngest child. If we place the celebration of Seder into the general setting of a permanent learning process, one may conclude that learning is successful when the focus is on the question. Most often the roles are being exchanged during the teaching process of the Seder. In an ordinary class the teacher usually asks the questions and the children have to give the answers, but here the child asks the question too. The child learns from what he/she sees on the table in front of him/her. The symbols represent both slavery and redemption, from the bitter herbs to the wine. In this way the child learns about both the good and the bad events in life. A very important element during this celebration is the transmission of faith from one generation to another. Good teaching is focussed on the discovery of the self's own dignity and identity (Poorthuis 1989:30).

\subsection{The Omer}

"You shall bring in the sheaf of the first fruits of your harvest to the priest. And he shall wave the sheaf before the Lord for you to be accepted; on the day after the Sabbath the priest shall wave it .... You shall count fifty days to the day after the seventh Sabbath; then you shall present a new grain offering to the Lord" (Lv 23:10, 11, 16). On the first day of the week following Passover, the cereal harvest began. The first grain to ripen, of those sown in winter, was barley: an "omer" is a half gallon of barley. The sheaf was reverently cut and the barley removed, filling a bowl, which was taken to the temple in this 
symbolic way and presented to the Lord of the harvest as an expression of thankfulness (Zimmerman 1981:96).

Writes Zimmerman (1981:97): "On the morrow of the Sabbath" following Passover, as the first fruits of the barley harvest were being offered in the Temple, Christ was "raised from the dead, the first fruits of those who are asleep" (1 Cor 15:20). Fifty days later, while the followers of Jesus were gathered together celebrating the Festival of Pentecost (or Shavuot), God gave them the gift of his Holy Spirit.

Zimmerman (1981:98-102) suggests that Christian families could gather on a convenient time every day to count down the fifty days, waiting for the Shavuot. This "in between" time could be filled with a dual celebration of the event at Sinai when God presented Israel with the Ten Commandments, and the event at Pentecost when God gave the Holy Spirit: a daily family service could be held with readings from different Psalms.

Hippolytus (Carrington 1957:336-350) advised Christians also to preserve some of the old Jewish rites as separate features: the offering of first-fruits, for instance, and the benedictions over various gifts of nature. The agape or love-feasts, where some rich person gives a supper in the evening for less privileged people, could be perfectly integrated into a Christian way of living today.

The "Zamen op weg" churches in the Netherlands have incorporated a First Fruit or Harvest Festival (every last Sunday of October) into the liturgical rhythm of their church year - thanking God for the harvest and for labour possibilities. In non-agricultural areas, processed products would be brought to church on such a day, specifically thanking the God of the harvest (Van der Beld 2005).

\subsection{Shavuot}

This Hebrew festival announced in the Old Testament and celebrated in the New Testament is known by a variety of names. Seven weeks after the second day of Passover occurs the festival called Shavuot, Feast of Weeks (late spring), or Pentecost. Shavuot is the Hebrew word for "weeks" and Pentecost is the Greek word for "fiftieth" (Zimmerman 1981:104; Sandmel 1978:24). In Old Testament times farmers brought their first-fruit offerings of barley to the Temple on the day after the Sabbath, at Passover. On that day the counting of the weeks began and, seven weeks later, Shavuot celebrates the first fruit of the wheat harvest. An early command regarding this celebration is found in Exodus 23:16, 19: "You shall observe the Feast of the Harvest of the first fruits of your labors from what you sow in the field .... You shall bring the first fruits of your toil into the house of the Lord your God." 
Because of this command the festival became known as the "Feast of Harvest" and the "Day of the First Fruits." The instructions in Leviticus 23:1517 prescribe that,

You shall also count for yourself from the day after the Sabbath, from the day when you brought in the sheaf of the wave offering; there shall be seven complete Sabbaths. You shall count fifty days to the day after the seventh Sabbath; then you shall present a new grain offering to the Lord. You shall bring in from your dwelling places two loaves of bread for a wave offering, made of two-tenths of a bushel; they shall be of a fine flour, baked with leaven as first fruits to the Lord.

Yet another significance (not found in the Bible) associated with this time is that it came to be recognized as a memorial of the revelation of the Torah, God's gift of the Ten Commandments at Mt Sinai, on the fiftieth day after the Israelites were led out of Egypt (Ex 19): "Remembering the anniversary of the covenant between God and Israel, it is called the season of the giving to us of our Holy Torah" (Zimmerman 1981:105; cf Sandmel 1978:218). Unlike Passover and Sukkot, Weeks or Pentecost is not marked by any special or notable observance (Sandmel 1978:218). Also, no Mishna tractate is read on Shavuot; the festival is only spoken of as an atzeret, for it was conceived of as "closing" the Passover (Sandmel 1978:217).

In this regard Zimmerman (1981:106) refers to Acts 2:1-4: "And when the day of Pentecost had come, they were all together in one place," celebrating this festival of the first fruits of the wheat harvest, "and they were all filled with the Holy Spirit, becoming the 'first fruit' of God's Holy Spirit. The Holy Spirit came on Pentecost to fulfill the prophecy of David (Ac 2:33-36) so that Christ would be recognized by Israel and known as the Son of the living God" (Zimmerman 1981:106).

Many Hebrew families used to camp on the hills around Jerusalem the night before the gifts were offered. Symbolic meals were eaten and on the day of the celebration carefully prepared presents were taken to the temple. People living far from Jerusalem would bring their best dried fruits, olives, dates and raisins. Those living nearby would offer fresh food from their harvest. Each family brought two loaves of their finest bread. According to Jewish tradition it is the custom to stay up the entire night of Shavuot, studying and discussing God's Word. It is traditional to read the book of Ruth because the narrative takes place in Bethlehem during harvest time (Zimmerman 1981:106-107). 
Zimmerman (1981:108-109) is convinced that this celebration could once again be used to build strong relationships between family members, who generally do not spend time together like this. She suggests that Christians should choose a place where they could be close together, spending time together in prayer and Bible study (cf Ps 119:148; Lk 6:12; 2 Tm 3:16,17; Mt 18:1-4; Pr; Ac 2:1-13; Jn 15 etc) and enjoying special meals together (including some of the above mentioned).

\subsection{Rosh Hashanah, a day of blowing}

The Hebrew word "Rosh" denotes "head" or "beginning" while "Hashanah" means "the year". The more common biblical name is "The feast of trumpets". This celebration of the New Year is not in conflict with New Year's Day, January 1, but is intended to be a celebration marking a "spiritual" new year, a special time set apart for a new beginning with the Lord (Zimmerman 1981:126). Every New Year the people of Israel held before their eyes the wonder of God's creation (Chupungco 1992:21; Sandmel 1978:221) and experienced in some mysterious way the recurrence of the cosmogonic time, which the New Year celebration aimed to recapture and transport to the present. In rabbinic thought, the New Year day is the Day of Judgment, quite as much as the anniversary of Creation (Sandmel 1978:221).

Hebrew festivals are calculated according to the lunar calendar and in keeping with tradition it is fitting that the seventh month is holy, just as the seventh day has always been honored. The beginning of the month Tishri (seventh) generally falls some time in September. The biblical data concerning the New Year festival are relatively scant. Leviticus 23:24 calls this day Yom Teruah, the Day of Sounding the Trumpet: "Speak to the sons of Israel, saying, 'In the seventh month on the first of the month, you shall have a rest, a reminder by blowing of trumpets, a holy convocation"'. In Numbers 29:1, the same content appears though the wording is altered. Verses 2-6 proceed to the details of the obligatory sacrifice and its accompanying requirements of a grain offering. Both these passages contain the commandments, but neither uses the phrase "New Year's Day". Sandmel (1978:221) is certain that Psalm 81:3: "Sound the trumpet on the new moon, on the full moon for the day of our festival" was brought into relationship with the New Year and became conceived of, as it is today, as a psalm for this occasion. The ritual of blowing the ram's horn grew out of Genesis 22:13, 14 and the account of Isaac being spared, often referred to as the sacrifice of Isaac. According to tradition the bend in the shofar represents a human heart in true repentance bowing before the Lord. It was sounded as a means of 
drawing God's attention, so as to be remembered and protected by Him (Nm $10: 9,10)$.

This day is the beginning of ten days called the "The High Holy Days", or "Days of Awe"; also termed Days of Repentance, Days of Returning, Days of Admittance. The observance concludes with Yom Kippur, the "Day of Atonement" (which was to be held on the tenth day; cf Lv 23:27; Zimmerman 1982:127, 128; Chupungco 1992:22). The people's repentance should commence on the New Year in association with its character as the Day of the Trumpet-Blast $^{7}$ (Sandmel 1978:222), a significant day of remembrance. The sounding of the shofar is a symbolic signal to God's people that it is time for a spiritual awakening.

The "Zamen op weg" churches in The Netherlands use the first Sunday of October to celebrate a special "Israel day". On this occasion the Jewish New Year and Yom Kippur are commemorated (Van der Beld 2005).

\subsection{Yom Kippur, a day of returning}

Yom Kippur, meaning the Day of Atonement (at-one-ment with God), occurs on the tenth day of Tishri. As noted above, it is the climax of ten days of repentance (Zimmerman 1981:146). This is the day that worshippers stand before God Almighty and have to confess their mistakes and admit they have sinned (cf Lv 16:29-34). The Day of Atonement embodied the annual recognition of the need to atone for one's guilt. Most of the other festivals celebrated events in Israel's past. Neither the quantity of sins, nor their quality, need make any person hesitate to follow the Divine call to repentance (Tyson 1973:101-103; Sandmel 1978:216). The high priest was the chief mediator between God and his people; he performed the sacrifice on the Day of Atonement and presided at sessions of the Sanhedrin ${ }^{8}$ (Tyson 1973:105).

\footnotetext{
${ }^{7}$ In the synagogue liturgy, a threefold prayer arose in connection with the ceremony of the trumpet - a shofar (ram's horn) rather than a metal instrument was and is used. As to the musical notes to be sounded on the shofar, much is obscure. A passage in the Mishna Rosh Hashana 4.9 speaks of three types of sounds, tekia, shebarim and terua, apparently entailing blasts of different length or of form. The tekia was a single, long note, shebarim a series of three sets of tonic-dominant, and terua a quickly repeated set of nine, but ending on the dominant (on a musical scale "do" is the tonic and "sol" the dominant) (Sandmel 1978:222).

${ }^{8}$ Several examples of post-Talmudic prayers to angels can be found in the Jewish service even today. One such invocation is the piyyut generally included in the prayers for forgiveness recited before and after Rosh Hashanah. The petitioner turns to the angels, asking them to pray on his/her behalf and to intervene for him/her so that his/her prayers and outcries come before God, as if the angels were the "gatekeepers" or guards of God's palace, determining what God should and should not hear. A similar plea is voiced in the song recited in the $\mathrm{Ne} \mathrm{c}$ illah service (the concluding service of Yom Kippur, the Day of Atonement): "Angels of mercy, servants of the Supreme, accost God with the best thoughts, perhaps he will show pity to the poor begging people [perhaps he will show pity]" (Goldschmidt 1965:11, 12; Bar-Ilan 2004:80, 81).
} 
Zimmerman (1981: 47) refers to New Testament passages that could be used to celebrate this special day in a Christian home or church, for example James 2:10, 1 John 1:8, 10, to remind Christians of their sin and the need to repent. Passages such as Galatians 3:29; Hebrews 7:26-28; 8:7, 8; 10:1-22 could also be read in a Christian context. She is also convinced that the parable told by Jesus about two men standing before God (Luke 18:15), took place on Yom Kippur. It is customary in the Hebrew tradition for fathers and mothers to bless their children on the day before Yom Kippur. Matthews 19:13 records: "Then some children were brought to him so that He might lay his hands on them and pray." Zimmerman encourages Christians to proceed with this ritual - to lay your hands on your children, touch them, and bless them in Jesus' name, and to take this opportunity to show your children how very much you love them.

Shortly before sundown, after blessing the children, the thoughtful custom takes place of lighting a memorial candle in memory of a loved one who has passed away that year. The next twenty-four hours have been designated for fasting and prayer. It is customary that, before Yom Kippur, right relationships be re-established, personal problems be resolved and disputes settled with the people around you (cf Mt 6:14, 16-18).

\subsection{Sukkoth, a family festival}

This festival begins on Tishre 15, two weeks after Rosh Hashanah. It is a harvest festival (possibly the ancestor of the American Thanksgiving) and is accorded a variety of names in the Bible. Sukkoth is the term in Leviticus 23:24; Deuteronomy 16:13, 16; Zechariah 14:16, 18-19 and elsewhere. In Exodus 23:16 and 34:22 it is the "Feast of the Ingathering" and in 1 Kings 8:2 and Ezekiel 45:23 it is simply called "The Feast". Probably "Ingathering" was an ancient harvest festival which developed into Sukkoth. The development included an alteration in the calendar from a solar dating ("at the cycle", "outgoing of the year") to the lunar dating of Tishre 15. Probably in very ancient times the "Ingathering" preceded and culminated in, the New Year (Sandmel 1978:455 no 24).

The symbols employed in the festival are the following: "On the first day, take the fruit of an eminent tree, branches of palms, boughs of leafy trees, and brook willows, and rejoice before the Lord for seven days." The Sadducees and the Pharisees were divided as to whether the fruit and the branches were to be used for the building of a structure at one's home or, instead, to be utilized quite apart from such a structure. In public worship Psalm 118 was recited. Hymns of praise were sung to instrumental accompaniment on the first night. The festivity, song and dance lasted until 
dawn. The injunctions regarding Sukkoth in Leviticus 23:41-43 prescribe that all natives to Israel are to dwell in the sukka for seven days, because the Israelites had dwelled in sukkoth when God had brought them out of Egypt. No such narrative exists (Sandmel 1978:216). Sandmel (1978:216) comments that Exodus 12:37 does speak of the Exodus journey from Raamses to Sukkot, and in 13:20 of the journey from Sukkot to the edge of the wilderness, but he argues that the Leviticus passage not only alters the place name into a term for booths, but, even more significantly, transforms a thanksgiving festival into an observance of a historic occasion. The home sukka was a rude building made of foliage. ${ }^{9}$

\section{CONCLUSION}

Many early Christian churches incorporated a number of non-biblical, even "pagan" symbols and rituals into their liturgy. It was contextualised into the church by according the celebration a brand new Christian content. From its first appearance Christianity made efforts to slander and suppress the pagan myths and rituals in the name of its own message, but this does not alter the fact that the church also sought some connections in the sphere of myth. Via the Christian interpretation, pagan gods increasingly came to be, as it were, equal partners with the biblical figures.

Some of the most important archaeological material, because it provides new insights into the world of the symbols and rituals and contributes to a new perspective on that world, has to do with the investigation of JewishChristian tombs as well as of inscriptions on church or synagogue floors. The rabbinic patterns of inhumation influenced Christian burial customs; and even the religious framework for the reestablishment of the church in Palestine and elsewhere shows how deeply interdependent church and synagogue were in their most formative period. From archaeological discoveries it has become clear that Jewish societies formed an integral part of those early Christian societies.

In that light, to contextualise Old Testament symbols and rituals for use in a Christian context should not be problematic. On the contrary, it contributes to a better historical-cultural understanding of the background of the New Testament. Those symbols and rituals will only enrich the religious experience of both family and church. I do not advocate that the Christian church should celebrate all the Old Testament rituals and practices, but I do consider that the church could at least be enriched by including or referring to

\footnotetext{
${ }^{9}$ Mishna Sukkot 1 and 2 provide in detail the building specifications as to size and roofing and inner supports, and the requisite rules for eating and sleeping in the sukka, and what to do if by chance rain falls.
} 


\section{Celebrating the feasts of the Old Testament in Christian contexts}

the symbolic meaning of some of those customs. Children (and even adults) learn best by what they see and experience: when something is demonstrated or ritually or symbolically experienced, real learning takes place. In Hebrew culture the children occupy a special place in the learning process. The belief exists that adults can learn much from the questions of children. Of course the Haggadah in the first place holds a unique significance for the Hebrew people, but in general it could also be significant for "didactical and religious insights" (Poorthuis 1989:14). An awareness of history itself is already an important element of the experience of liberation; therefore the celebration of Pesah is in itself already liberating in its dynamics and modern life lacking the dimension of an awareness of history is related to the slavery in Egypt.

In the early Christian church it might still have been necessary to draw a clear distinction between Judaism and Christianity, for obvious reasons. Christians do not need to fall into legalism again, but bringing the Old Testament traditions and background into consideration would almost certainly enrich Christianity today.

In general the early church fathers still exhibited some kind of loyalty to Judaism and the Old Testament, but indicated that new guidelines should be followed concerning the celebration of some of those festivals. The dual significance of festivals is emphasized: they are both a Jewish institution commemorating a historical event - and a "type" in the life of Jesus. Ample evidence exists that the first disciples of Jesus at least observed the feasts of Passover, Unleavened Bread and Pentecost. The feasts that remained in early Christianity encompassed Passover (Shavuot) and Sabbath (mitzvhot and halachat were abandoned) - the emphasis was on the Sabbath as the pre-eminent weekly day of prayer along with Scripture reading.

Inculturation does not necessarily involve a change in the existing patterns and elements of any feast: it requires a change of perspective, a new manner of understanding the meaning of that feast. If Christians have a choice between integrating a "surplus" from the Old Testament (from which the symbolic language of Christianity stems), or integrating a "surplus" from other religions (e g European paganisms or other "religions") it seems logical to select the first option. The Old Testament has an abiding significance for Christianity which should not be neglected.

\section{Works consulted}

Bar-Ilan, M 2004. Prayers of Jews to angels and other mediators, in Poorthuis \& Schwartz 2004:79-95.

Betz, H D 1998. Antike und Christentum: Gesammelte Aufsatze, IV. Tubingen: Mohr. 
Brown, P 2003. The rise of Western Christendom: Triumph and diversity AD 200$1000,2^{\text {nd }}$ edition. Oxford: Blackwell.

Carrington, P 1957. The early Christian church, vol II: The second Christian century. Cambridge: Cambridge University Press.

Chupungungo, A J 1992. Shaping the easter feast. Washington, DC: Pastoral.

David, R 2005. Private communication. Taize: France.

De Vries, J 1935. Altgermanische Religionsgeschichte: Einleitung in die Vorgeschichtliche Zeit: Religion der Sudgermanen. Berlin: Gruyter

Du Plooy, $\mathrm{N}$ et al 2000. Preekstudies met liturgiese voorstelle gebaseer op die leesrooster vir lidmate. Revised Common Lectionary. Advent 2000 tot Koninkrykstyd 2001. Jaar C. Matieland: Buro vir Voortgesette Teologiese Opleiding en Navorsing.

Fabbro, F 1999. Did early Christians use hallucinogenic mushrooms? Archaeological evidence. Eleusis: Journal of ancient religions. (Psychedelic plants and components 3.) (http://people.etnoteam.it/maiocchi/fabbio.htm)

Fawcett, T 1970. The symbolic language of religion: An introductory study. London: SCM.

Frend, W H C 1976. Religion popular and unpopular in the Early Christian centuries. London: Variorum.

Frend, W H C 1988. Archaeology and history in the study of early Christianity. London: Variorum.

Geerlings, W (ed) 1991. Tradition Apostolica. Freiburg: Herder. (Fontes Christiani 1.)

Goldschmidt, D 1970. Mahzor for the days of Awe, 2, Yom Kippur. Jerusalem: Koren.

Houtepen, A 2004. A holy Father on the see of Moses?, in Poorthuis \& Schwartz 2004:433-456.

Le Roux, M 2005. African light on the New Moon ceremony. Old Testament Essays, 18(2), 281-295.

Owen, J 2005. Catacomb find boosts early Christian-Jewish ties, study says. http://news.nationalgeographic.com/new/2005/07/0720 050720 christianity.html

Pieterse, H J C \& Müller, J C 19[99]. Kerkjaar, simboliek en die kerklike drag van die liturg. Ongepubliseerde inligtingstuk vir die NG Kerk.

Poorthuis, M 1989. Hamer op de rots. Hilversum: B Folkertsma Stichting voor Talmudica.

Poorthuis, M \& Schwartz, J (eds) 2004. Saints and role models in Judaism and Christianity. Leiden: Brill. (Jewish and Christian Perspectives Series.)

Rahner, H 1963. Greek myths and Christian Mystery. London: London: Burns.

Rutgers, L V 2004. Ziel en zaligheid: De late oudheid vanuit godsdiensthistorisch en archeologisch perspectief. Amsterdam: Koninklijke Nederlandse Akademie van Wetenschappen.

Sandmel, S 1978. Judaism and Christian beginnings. New York: Oxford University Press.

Seznec, J 1972. The survival of pagan gods: The mythological tradition and its place in renaissance, humanism and art. Princeton, NJ: Princeton University Press.

Tyson, J B 1973. A study of early Christianity. New York: Macmillan.

Van Bekkum, W 2004. The rock on which the church is founded, in Poorthuis \& Schwartz 2004:289-310. 
Van der Beld, R 2000a. Orden van dienst voor de stille week: Inlichtingstuk, Ongepubliseerd. Noorderkerk, Bilthoven: Nederland.

Van der Beld, R 2000b \& 2005. Private communication. Bilthoven: The Netherlands.

Vriezen, K J H 1998. Inscriptions in Mosaic pavements in Byzantine Palestina/Arabia quoting texts from the Old Testament, in Rutgers, L V, Van der Horst, P W, Havelaar, H W \& Teugels, L (eds), The use of sacred books in the ancient world, 247-261. Leuven: Peeters.

Wessels, A 1994. Europe: Was it ever really Christian? The interaction between gospel and culture. Baarn: Ten Have.

Zimmerman, M 1981. Celebrate the feasts of the Old Testament in your own home or church. Minneapolis, MN: Bethany. 